\title{
Archipel
}

ARCHIPEL Études interdisciplinaires sur le monde insulindien

102 | 2021

Varia

\section{Mona Lohanda (1947-2021) Remembered: Humble Gatekeeper of the Indonesian National Archives, Historian of the Batavian Chinese and True Daughter of Tangerang}

Peter Carey

\section{(2) OpenEdition}

Journals

Édition électronique

URL : https://journals.openedition.org/archipel/2612

DOI : 10.4000/archipel.2612

ISSN : 2104-3655

Éditeur

Association Archipel

Édition imprimée

Date de publication : 31 December 2021

Pagination : $9-18$

ISBN : 978-2-910513-87-0

ISSN : 0044-8613

Référence électronique

Peter Carey, « Mona Lohanda (1947-2021) Remembered: Humble Gatekeeper of the Indonesian National Archives, Historian of the Batavian Chinese and True Daughter of Tangerang », Archipel [En ligne], 102 | 2021, mis en ligne le 15 décembre 2021, consulté le 15 décembre 2021. URL : http:// journals.openedition.org/archipel/2612 ; DOI : https://doi.org/10.4000/archipel.2612 


\section{Mona Lohanda (1947-2021) Remembered: Humble Gatekeeper of the Indonesian National Archives, Historian of the Batavian Chinese and True Daughter of Tangerang}

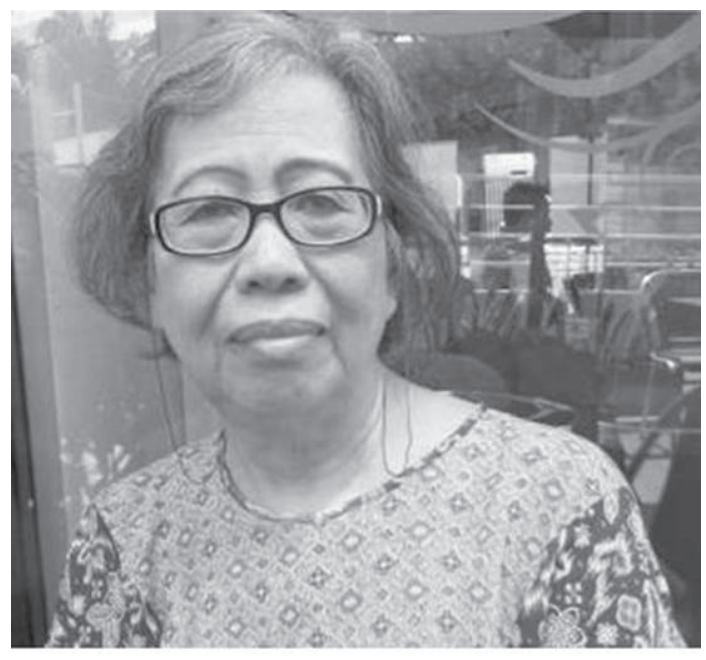

Mona Lohanda (19472021), whom I always knew as 'Nona Mona,' was that truly rare phenomenon in the world of Indonesian archivists and historians, a person of integrity. Throughout her forty-year career as an archivist at the Indonesian National Archives (ANRI), she became the gatekeeper to the VOC (Dutch East India Company) records held in Jakarta (pre1942, Batavia). Her role as Assistant Conservator

(Deputi Pembinaan Kearsipan) at ANRI between September 2005 and December 2007, was central to the success of the TANAP (Towards A New Age of Partnership) project (1999-2007), which involved a major cooperation between the Dutch National Archives (Nationaal Archief) in the Hague, Leiden University and ANRI for the training of young researchers and curators in the seventeenth and eighteenth-century VOC archives. Mona's key position made possible the opening of the largest collection of VOC documents in the world - some two kilometres archives comprising nearly ten million pages of 
documents at ANRI, one million of which are now accessible online thanks to the website established by the project head, Dr Pieter Koenders of Leiden University (http://www.tanap.net/).

During these two and a half years, when she was Assistant Conservator, nearly all these documents were re-backed with acid free paper, sorted and reboxed in one of the most fundamental reorganisations of ANRI since its inception as the colonial government archive (Landsarchief) in 1892 under Jacobus Anne van der Chijs (1831-1905; in office, 1892-1905), the first landsarchivaris. Mona's detailed knowledge of the archive, her no-nonsense approach to her work, linguistic skills and willingness to speak her mind both to her ANRI and Dutch colleagues made her an outstanding member of the TANAP team. Here she was fortunate in her good working relationship with the ANRI Head, Drs Djoko Utomo (in office, 2004-2009), who was in post in the last period of this project. Pak Djoko shared her enthusiasm and fluency in English and together they made an impressive team during their regular visits to the Netherlands to consult with their Dutch historian and archivist counterparts. It is very unlikely that the TANAP programme would have been the success that it was without Mona's presence.

As Assistant Conservator, Mona had overall control over 75 percent of the daily curatorial budget of ANRI. Her frugality and intense dislike of the ubiquitous projects (proyek-proyekan) with which her senior ANRI colleagues topped up their exiguous civil servant salaries made her position increasingly invidious. In December 2007, just four and a half years before her retirement in mid-2012, she decided to step away entirely from her senior management position. Instead, she secured a small private office for herself on the first floor of the conservation department and began her archival swansong, namely her painstaking transcription of the textual summaries - marginalia - of the 165 volumes of the "Daily Journals of the Castle of Batavia [Daghregisters van het Casteel van Batavia]," covering the 124 years between 1683 and $1807 .{ }^{1}$ During the space of two years (2008-10) she developed a corpus of research which, when taken further by the Corts Foundation VOC archive digitization

1. The Daghregisters (Daily Journals of Batavia Castle) for the earlier period (1624-1682) were published in 31 volumes between 1887 and 1931 with the first nine volumes being funded by the Dutch Ministry of the Colonies and published in the Hague, and the remaining twenty-two being supported by the Batavian Society of Arts and Sciences (Bataviaasch Genootschap van Kunsten en Wetenschappen, BG). The three first Directors of the Landsarchief (colonial government archive) in Batavia, J.A. van der Chijs (in office, 1892-1905), Frederik de Haan (in office, 1905-1922) and E.C. Godée Molsbergen (in office, 1922-1937), oversaw the transcription and editing of these final BG-sponsored volumes. Amounting to 16,175 pages of documents and 754 pages of indexes, the volumes constitute the single most important published source for the pre-1800 period and have facilitated a range of significant studies on the maritime history of Southeast Asia. They are all available online at https://sejarahnusantara.anri.go.id/daily_journals_volumes/ 
project (2010-16), later formed the basis of an online 'Open Sesame' which late seventeenth and eighteenth-century historians the world over could use to unlock the day-to-day workings of the Dutch East India Company's operations in Asia. Hendrik E. Niemeijer, the lead historian for the Corts Foundation digitization project, and Mona's initial work on the marginalia, amounting to 5,500 pages of transcriptions, was converted into a database of 117,392 records, which were then connected to the scans of the individual pages of the original Daghregister volumes. Building on Mona's pioneering work, which even involved Mona recreating the marginalia entries for those early Daghregister volumes (1624-59) where they were missing, Niemeijer and his team were able to isolate all records containing information on arriving and departing vessels, and all incoming and outgoing diplomatic letters. It was the first time that a VOC archive had been made accessible with modern digitalization techniques and many international researchers have profited from this hugely important online resource now accessible at https://sejarahnusantara.anri.go.id/marginalia/. ${ }^{2}$

During her four-decade career as an archivist (1972-2012), Mona became a walking dictionary of her native city knowing the exact dates of all the earthquakes, floods, local rebellions, uprisings, epidemics, pestilences and political crises which afflicted the Dutch colonial capital in the VOC period (1619-1799). This made her the 'go-to' person for Indonesian and foreign researchers alike interested in the VOC archives, and the history of Indonesia in the seventeenth and eighteenth centuries more generally. By 1993, she had risen to the key position of Head of the ANRI Reading Room (Pemimpin Ruang Baca), a post which she held for over a decade until her promotion as Assistant Conservator in September 2005. She was thus officially the conduit through which all researchers at the Indonesian National Archives accessed ANRI's rich historical resources. During this time, she worked closely with a number of leading Dutch historians and scholars of Indonesia. These included Karel Adriaan Steenbrink (1942-2021), a specialist in comparative religion based at the Interuniversity Institute of Missiological and Ecumenical Research (IIMO) in Leiden who wrote a well-regarded trilogy on the Catholic Church in the Netherlands Indies/Indonesia from 1808 to the Reformasi Era (1998-present); ${ }^{3}$ the Head of the Koninklijk Instituut voor Taal-, Land- en

2. This unique online resource was published by the Leiden VOC historian, Dr Henk E. Niemeijer, known for his book Batavia: Een koloniale samenleving in de 17de eeuw (Amsterdam: Balans, 2005), translated as Batavia: Masyarakyat Kolonial Abad XVII (Jakarta: Masup, 2012). Together with Marco Rolling, an information analyst, Niemeijer carefully checked and, where necessary, re-transcribed, the 5,500 pages of transcriptions originally compiled by Ibu Mona. Once converted to Excel, these delivered some 117,392 records which were then uploaded to ANRI's website (anri. go.id) via the MAIS-Flexis archival system in Nijmegen.

3. Steenbrink's Catholic Church in Indonesia trilogy include: (1) Catholics in 
Volkenkunde (Royal Institute for Linguistics and Anthropology; post-2003, Royal Netherlands Institute of Southeast Asian and Caribbean Studies) representative office in Jakarta, Dr. Jaap Erkelens (in post, 1977-2003), as well as with Professor Pieter J. Drooglever (1941-2017). The last briefly held the L.J. Rogier chair of Dutch-Indonesian Relations at the University of Nijmegen (in post, 1995-98) when Mona was also studying at Radboud University in the selfsame south-eastern Dutch city close to the German border.

Mona's unparalleled knowledge of the ANRI holdings of Dutch colonial archives proved invaluable for Drooglever during his multi-volume editing task (1969-2006) of the documents on the decolonisation in Indonesia between 1945 and 1950 at the Huygens Institute of Netherlands History (Huygens Instituut voor Nederlandse Geschiedenis, ING) in The Hague, particularly the final volumes covering the period $1948-50 .{ }^{4}$ As a result of this cooperation, Mona was invited by Drooglever and his colleague, M.J.B. Schouten, to become joint editor of a guide in English to these decolonisation sources, Guide to the Archives on relations between the Netherlands and Indonesia, 1945-1963 (The Hague/Den Haag: Institute of Netherlands History/ING). In this case, the guide took the story right through to 1963, namely President Sukarno's (in office 1945-66) successful campaign to "regain" West Irian (now Papua) on which Peter Drooglever also published a highly critical collection of documents questioning the transparency of the UN involvement. ${ }^{5}$

Mona's involvement with Drooglever, together with his temporary professorial appointment in Nijmegen, may have been one of the reasons that Mona decided to pursue her doctorate at Radboud University. She might have seen this as the logical conclusion of her academic career which had run parallel with her duties at ANRI in the 1990s. We know that she had been encouraged

Indonesia,1808-1942: A documented history. Volume I: A modest recovery, 1808-1903 (Leiden: KITLV Press, 2003); (2) Catholics in Indonesia,1808-1942: A documented history. Volume II: The spectacular growth of a self-confident minority, 1903-1942 (Leiden: KITLV Press,2007); and (3) Catholics in Independent Indonesia, 19452010 (Leiden: Brill, 2015). All three volumes have been translated into Indonesian by Yosef Maria Florisan of the Sekolah Tinggi Filsafat Katolik Ladalero in Maumere, Flores, and published by Penerbit Ledalero under the title, Orang-orang Katolik di Indonesia, 1808-1942 and Orang-orang Katolik di Indonesia era Kemerdekaan 1945 2010 (2006, second revised ed. 2018).

4. Officiële bescheiden betreffende de Nederlands-Indonesische betrekkingen, 19451950, S.L. van der Wal, P. J. Drooglever and M.J.B. Schouten (eds). The Hague/Den Haag: Institute of Netherlands History/ING, 20 volumes. 1969-2006. Available online at http:// resources.huygens.knaw.nl/retroboeken/nib/\#page=0\&accessor=toc\&view=homePane.

5. Pieter Drooglever, An Act of Free Choice: Decolonisation and the Right to SelfDetermination in West Papua (Oxford: OneWorld Publications, 2009). On the August 1969 "Act of Free Choice" (dubbed the "Act of No Choice" by critics) in West Papua (then West Irian), see John Saltford, The United Nations and the Indonesian Takeover of West Papua, 1962-1969. The Anatomy of Betrayal (London: RoutledgeCurzon, 2003). 
by Prof. Harsja Bachtiar (1934-1995), the Dean of the Fakultas Sastra at the University of Indonesia during her BA studies in history in the period 1971-1975 to develop her historical interests in the history of the Chinese community in Batavia. This resulted in her choosing to write her MA (S2) thesis at the School of Oriental \& African Studies (SOAS) in London under the supervision of Dr Ian Brown, a specialist on the economic history of colonial Burma and Siam (Thailand), on the Kapitan Cina (Captains of the Chinese Community) in Batavia in the period 1837-1942. This became her most important scholarly publication, which remains to this day a key work of reference. ${ }^{6}$ But her attempt to take her SOAS degree a stage further and undertake a doctorate in Nijmegen at Drooglever's urging was not a success. After a year at Radboud, her thesis proposal on the history of the Chinese community in Indonesia was rejected by her academic supervisory committee as lacking focus and academic rigour and she returned to Jakarta with the consolation prize of an MPhil degree. Her academic failure may have been the spur for her own initiative on the transcription of the marginalia which she did entirely of her own bat-virtually unsung and unsupported by her senior ANRI colleagues.

In the interstices of her archival duties, ongoing marginalia transcriptions and her teaching as a lecturer at the History program (Prodi Sejarah) at the University of Indonesia (1978-2012), where she lectured in palaeography, sharing her archival skills in seventeenth and eighteenth-century Dutch historic handwriting, Mona found time to publish the materials she had researched in Nijmegen for her aborted $\mathrm{PhD}$ thesis, bringing out her book on Sino-Dutch relations in the last fifty years of the Netherlands Indies under the imprint of Pastor Adolf Heuken SJ's press, Growing Pains: The Chinese and the Dutch in Colonial Java, 1890-1942 (Jakarta: Yayasan Cipta Loka Caraka, 2002). ${ }^{7}$ Her unwavering dedication and professionalism was recognised by the Indonesian Government with a merit award (Satyalencana Karya Satya) on the completion

\footnotetext{
6. Mona Lohanda, The Kapitan Cina of Batavia 1837-1942: A History of Chinese Establishment in Colonial Society. Jakarta: Djambatan, 1996 (reprinted in a revised edition 2001). To date, this work, Mona Lohanda's most important scholarly study, has yet to be translated into Indonesian.

7. In August 2009, plans to bring out an Indonesian translation of a section of this work entitled "Tionghoa dan Kewarganegaraan Indonesia: Kilas balik sejarah" as the second chapter of a planned Instituut Kewarganegaraan Indonesia (IKI) volume on the history of Indonesian citizenship were not realised. But, in 2017, Mona was invited to serve with Indradi Kusuma as co-editor of a volume written by Eddy Setiawan et al. and entitled Mengabdi tak kenal henti: Perjuangan mewujudkan WNI tunggal [To Serve Knows No End: The Struggle to create a single Indonesian Citizenship] (Jakarta: Institut Kewarganegaraan Indonesia/IKI), in which some of her work from her unpublished 2009 chapter was used in the book's second chapter, 'Sejarah Kewarganegaraan Indonesia [The History of Indonesian Citizenship].' I would like to thank Pak Didi Kwartanada for this information, electronic communication, 30 March 2021.
} 
of her twenty years of service as a senior ANRI archivist on 16 August 2001, ${ }^{8}$ and by Eddie Lembong's Yayasan Nation Building which gave her a Nabil Award in October 2010 for her contribution to Indonesian nation-building. ${ }^{9}$ At the same time, the quality of her historical research, academic publications and allied scholarly activities, such as her pioneering work on the VOC archives, also garnered her other prestigious accolades. These included a "Cendekiawan Berdedikasi [Dedicated Intellectuals]" Award as part of the newspaper's 47th anniversary celebrations on 27 June 2012, which coincidentally marked her retirement from her archival duties at ANRI, ${ }^{10}$ an honour followed four years later by the equally prestigious Achmad Bakrie prize (19 August 2016) in recognition of her lifetime contribution (sumbangsih) and dedication to raising up the historiographical value of the Indonesian national archives for international scholarship. ${ }^{11}$

Mona was a proud Cinbeng (Cina Benteng), a Chinese-Indonesian peranakan from Tangerang, descendant of those peranakan families moved from Batavia to the area around the fort on the Kali Cisadane which marked the boundary between the Batavian environs (ommelanden) and the sultanate of Banten following the Chinese massacre in the colonial capital on 9 October 1740. Immediately recognisable by her booming voice, she did not suffer fools gladly, commenting once that one of the prominent historians who was honoured with her in 2010 by Eddie Lembong's Yayasan Nation Building (Yayasan Nabil) only wrote "books about books" and had never done any serious archival research. She also hated flying abroad for conferences, having a particular dislike of Singapore where she said even the most fleeting visit made her feel unwell given its remorseless and driven quality. Shades here of Muhammad Hatta (1902-1980), who vowed never to set foot in the island republic after the two Indonesian marines (Korps Komando Operasi, KKO), Sergeant Usman Janatin (1943-1968) and Corporal Harun Thohir bin Mandar (1943-1968), were hung by the Singaporean authorities after multiple appeals for clemency had been rejected.

A devout Catholic and close to the great Jesuit historian of colonial Batavia, Pastor Adolph J. Heuken SJ (1929-2020), Mona spent most of her retirement years sorting through the disordered archive of the Jakarta Catholic archbishopric (Keuskupan Agung) and the Indonesian Catholic bishops' conference (Konferensi Waligereja Indonesia, KWI). She just loved helping people she liked while understandably bearing a grudge against people she

8. SK [Surat Keputusan] Presiden RI no: 087/TK/tahun 2001, 16 August 2001, which awarded her a Piagam [Certificate] Tanda Kehormatan Satyalencana Karya Satya.

9. "Tiga Sejarawan Terima Nabil Award," Kompas, 14 October 2010; Didi Kwartanada, Nabil Award 2010: Memahami sejarah, membangun bangsa (Jakarta: Yayasan Nabil, 2010).

10. “'Kompas’ Anugerahi 5 Cendekiawan Berdedikasi,” Kompas, 27 June 2012.

11. "Penghargaan Achmad Bakrie XIV 2016," YouTube, tvOne News, 25 October 2016. 
felt were time wasters. I felt from our brief encounters at the launch of my Kuasa Ramalan (Power of Prophecy) biography of Prince Diponegoro (17851855) at the National Library at Salemba on 12 April $2012^{12}$ and the 23-25 November 2018 Borobodur Writers and Cultural Festival that I fell into the first category. But, since I had completed my doctoral research in ANRI in the early to mid-1970s $(1971,1976-77,1978)$ before Mona's archival career really took off, I did not have the benefit of her encyclopaedic knowledge of the Dutch colonial archives, and never really knew what she thought of me! My last meeting with her was at Bethesda Hospital in Gading Serpong on 6 June 2020 when she was being treated for high blood pressure a result of her underlying diabetic condition which would later cause her fatal heart attack on 16 January 2021. Sadly, she is irreplaceable as she was one of a kind. Rarely does one find people of her dedication and integrity in the contemporary world of Indonesian academia and archives. But her life oeuvre will live on through her selfless work on the VOC archives and in the memories of the countless scholars she has helped the world over through her unstinting sharing. Where indeed would the Indonesian National Archives have been without her?

Peter Carey was Laithwaite Fellow and Tutor in Modern History at Trinity College, Oxford (1979-2008) and is currently (2013-present) Adjunct Professor at the Faculty of Humanities of the University of Indonesia (FIB-UI) in Jakarta.

\section{Selected Bibliography}

\section{(works written, jointly authored or edited by Mona Lohanda)}

\section{Monographs, articles and chapters}

Lohanda, Mona 1985. 'Mayoor Jansens [Mayor Jantje],' closing essay in, Burung-burung walet Klapanoenggal. Trans. Johan Fabricius, De Zwaluwen van Klapanoenggal (Den Haag: Leopold, 1979), pp.170-179. Jakarta: Pustaka Azet.

- 1986. Perjuangan dan Pengabdian: Mosaik kenangan Prof. Dr. Satrio 1916-1986. Jakarta: ANRI.

- 1990. Pandangan holistik terhadap sumber sejarah. Jakarta: Departemen Pendidikan dan Kebudayaan, Direktorat Sejarah dan Nilai Tradisional, Proyek Inventarisasi dan Dokumentasi Sejarah Nasional.

- 1996. The Kapitan Cina of Batavia 1837-1942: A History of Chinese Establishment in Colonial Society. Jakarta: Djambatan, 1996 [second revised edition published by Djambatan with the Koninklijk Instituut voor Taal-, Land- en Volkenkunde (KITLV), Perwakilan Indonesia, 2001].

12. "Sejarah Diponegoro: Buku karya Carey diluncurkan," Bisnis.com, 12 April 2012. The full title of the book being launched was Kuasa Ramalan: Pangeran Diponegoro dan Akhir Tatanan Lama di Jawa, 1785-1855 (Jakarta: KPG, 2012), a slightly expanded and revised Indonesian translation of The Power of Prophecy; Prince Dipanagara and the End of an Old Order in Java, 1785-1855. Leiden: KITLV Press, 2007. 
— 1997. "The 'Passen en Wijkstelsel': Dutch practice of Restriction Policy on the Chinese." Jakarta: Universitas Indonesia / Amsterdam: CASA (Centre for Asian Studies Amsterdam).

- 1998. Sumber sejarah dan penelitian sejarah. Depok: Pusat Penelitian Kemasyarakatan dan Budaya, Lembaga Penelitian, Universitas Indonesia.

- 2002. Growing Pains: The Chinese and the Dutch in Colonial Java, 1890-1942. Jakarta: Yayasan Cipta Loka Caraka.

— 2003. "Indonesia dalem Api dan Bara" Pustakaloka, Kompas, 16 July (English version of same article in International Journal of Asian Studies, 3:1 (January 2006):138-40).

- 2006. Karya-karya tentang Tionghoa: tinjauan singkat historiografis. Jakarta: ??

- 2007. Sejarah para pembesar mengatur Batavia. Depok: Masup.

— 2007. "Nie Ho Kong; tragedi seorang Kapitan Cina," foreword to the Indonesian translation of B. Hoetink, Ni Hoe Kong; kapitein Tionghoa di Betawie dalem taon 1740, pp.iii-xviii. Jakarta: Masup.

— 2007. "Konsistensi OHH," in David Reeve, JJ Rizal, Wasmi Alhaziri (eds.), Onze Ong; Onghokham dalam kenangan, pp.249-256. Jakarta: Penerbit Komunitas Bambu.

- 2008. "Sekolah THHK: Sang pemula dalam pendidikan swasta di Indonesia," Tapian, (majalah Budaya Batak), April, pp.23-26.

— 2008. "Perluasan Eksploitasi Ekonomi Kolonial," Fokus, Kompas, 22 August.

- 2008. "Majoor Jantje dan unsur Indo-Belanda dalam musik rakyat Betawi," foreword to Indonesian translation of Johan Fabricius, Major Jantje; cerita tuan tanah Batavia abad ke-19, pp.vii-xl. Jakarta: Masup.

- 2008. "Jalan Pos Daendels dan Perluasan Eksploitasi Ekonomi Kolonial," in Ekspedisi Anjer-Panaroekan; Laporan Jurnalistik Kompas, pp.85-90. Jakarta: Penerbit Kompas.

— 2009. "Menjemput surat dari raja; Ritual diplomatik abad kedelapan belas," in Sri Msargana and Widya Fitrianingsih (eds.), Perspektif lokal dan global: Persembahan 70 tahun Djoko Suryo, pp.514-520. Yogyakarta: Ombak.

— 2009. "Menjadi Peranakan Indonesia" and "Unsur Lokal dalam Ritual Peranakan," in Peranakan Tionghoa Indonesia; Sebuah Perjalanan Budaya, pp.34-55, 56-69. Jakarta: Intisari-Komunitas Lintas Budaya Indonesia.

— 2009. "Pengenalan Intelektual dengan Soe Hok-Gie," in Rudi Badil, Luki Sutrisno Bekti and Nessy Luntungan R. (eds.), Soe Hok-Gie ... sekali lagi; Buku pesta dan cinta di alam bangsanya, pp.389-400. Jakarta: KPG.

- 2011. Membaca Sumber, Menulis Sejarah. Yogyakarta: Ombak.

- (ed.) 2018. Bibliografi beranotasi sumber sejarah: Masa pendudukan Jepang di Indonesia. Jakarta: Direktorat Sejarah, Kemendikbud.

— 2020. "Pengantar Kumpulan Karangan Go Gien Tjwan," in Go Gien Tjwan, Tulisan Pilihan dari Pengasingan, pp.vi-ix. Jakarta: Yayasan Pustaka Obor Indonesia.

— 2020. "Sejarah Lisan dalam Kenangan Bersama Prof. Taufik Abdullah," in Susanto Zuhdi et al (eds.), 85 Tahun Taufik Abdullah: Perspektif Intelektual dan Pandangan Publik, pp.34548. Jakarta: Pustaka Obor.

\section{Jointly authored and edited works}

- 1980 (with Frans Haryadi and Yulianti Parani). Tanjidor: Sebuah laporan pengamatan lapangan kesenian Tanjidor di Daerah Jakarta dan sekitarnya. Jakarta: Lembaga Pendidikan Kesenian. 
— 1984 (with Iman Hilman, Bastori Ervan and Anhar Gonggong). Sejarah Sosial DKI Jakarta. Jakarta: Proyek Inventarisasi dan Dokumentasi Sejarah Nasional, Depdikbud.

- 1986 (with Erwiza Tanjung and Francisca Yuniarti). Sejarah peralihan pemerintah RIS ke RI: (menuju negara kesatuan Republik Indonesia). Jakarta: Proyek Inventarisasi dan Dokumentasi Sejarah Nasional, Depdikbud.

- 1996 (with Tim Penulisan Buku Kenangan ANRI). Arsip Nasional Republik Indonesia dalam gerak langkah 50 tahun Indonesia Merdeka. Jakarta: ANRI.

- 1998 (with Rahayu S. Hidayat). Sumber sejarah dan penelitian sejarah. Depok: Pusat Penelitian Kemasyarakatan dan Budaya, Lembaga Penelitian UI.

- 1999 (with Peter Drooglever and M.J.B. Schouten). Guide to the Archives on relations between the Netherlands and Indonesia, 1945-1963. The Hague: Institute of Netherlands History; Den Haag: ING.

- 2002 (with Andreas Pardede). Antara Prasangka dan Realita: Telaah kritis wacana anti Cina di Indonesia. Jakarta: Pustaka Inspirasi.

— 2005 (with Tri Wahyuni). Enam Dasawarsa perjalanan bangsa: Katalog Pameran 60 Tahun Kemerdekaan Republik Indonesia. Jakarta: ANRI.

- 2008 (with Depdikbud editorial team). Soedirman; patriotisme, gerilya dan martabat bangsa. Jakarta: Departemen Kebudayaan dan Pariwisata.

— 2008 (with Mary Somers Heidhues, Asep Salmin and Suma Mihardja). Timah Bangka dan lada Mentok: Peran masyarakat Tionghoa dalam pembangunan pulau Bangka abad XVIII d/d abad XX. Jakarta: Yayasan Nabil.

— 2017 (ed. with Indradi Kusuma). Eddy Setiawan et al. Mengabdi tak Kenal Henti: Perjuangan Mewujudkan WNI Tunggal. Jakarta: Institut Kewarganegaraan Indonesia [IKI].

- 2019 (with Kresno Brahmantyo and Wasmi Alhaziri). Mengenal Nama-nama Stasiun MRT Jakarta. Jakarta: Direktorat Sejarah, Dirjen Kebudayaan, Kemendikbud.

\section{Seminar papers}

- 1981. "Sumber sejarah lisan dalam penulisan sejarah kontemporer Indonesia". Seminar Sejarah Nasional ke-3 (Jakarta, 10-14 November 1981). Jakarta: Proyek Inventarisasi dan Dokumentasi Sejarah Nasional, Depdikbud.

— 1985. "Budaya 'Indisch' dalam konteks budaya Betawi: Subtema 3: Dinamika perkembangan sosial budaya bangsa Indonesia". Seminar Sejarah Nasional ke-4 (Yogyakarta). Jakarta: Proyek Inventarisasi dan Dokumentasi Sejarah Nasional, Depdikbud.

- 1990. "Pandangan holistik terhadap sumber sejarah". Seminar Sejarah Nasional ke-5 (Semarang). Jakarta: Proyek Inventarisasi dan Dokumentasi Sejarah Nasional, Depdikbud.

- 2001. "Korban politik, mangsa konflik: Warga Cina dan kekerasan oleh negara”. Konferensi Sejarah Nasional ke-7 (Jakarta). Jakarta: Proyek Inventarisasi dan Dokumentasi Sejarah Nasional, Depdikbud.

- 2002. "Indonesia-Tionghoa di bawah kekerasan kolonial: Tinjauan sosial-politik". Seminar Peran Etnis Tionghoa dalam Perjalanan Sejarah Indonesia. Jakarta: Perhimpunan Indonesia-Tionghoa (INTI).

— 2003. "Komunitas Tionghoa sebagai 'Bangsa Tengah'," Diskusi Bulan Purnama, Jaringan Kerja Budaya, Jakarta, 10 Oktober.

— 2004. "Sentimen Anti-Tionghoa, 1740-1998; sebuah renungan," paper for the "Peringatan 104-tahun sekolah THHK (Jakarta: Alumi Pa Hua)," March.

- 2005. "Paleis te Weltevreden itu ternyata bukan Istana," paper for Ikatan Arsitek Indonesia 
DKI Jakarta---Pusat Dokumentasi Arsitektur, Seminar Konservasi dan Dokumentasi, Penelitian Sejarah dan Pengukuran Gedung Departemen Keuangan, Jakarta, 1 April 2005.

- 2005. "Dari Chineesche Hospitaal menuju Jang Seng Ie; Kontribusi dan partisipasi Tionghoa dalam pelayanan kesehatan masyarakat," paper for Seminar Mengenal Sejarah RS Jang Seng Ie, RS Husada, Jakarta, 20 December.

— 2006. "Riwayat Peranakan Tionghoa atau sekedar Pelangi Kehidupan?," paper for book discussion of Onghokham, Riwayat Peranakan Tionghoa di Jawa, Museum Bank Mandiri, Jakarta, 26 February.

— 2006. "Karya-karya tentang Tionghoa: tinjauan singkat historiografis," paper for the Conference and Workshop 'Dekolonisasi dan Posisi Etnis Tionghoa Indonesia $1930 \mathrm{~s} / \mathrm{d}$ 1960-an', Nederlands Instituut voor Oorlogsdocumentatie-Universitas Negeri Padang, Padang, 19-21 June.

— 2006. "Oral History in Indonesia; A critical review," paper for Seminar on Collective MemoryCapturing the Past and Preserving in for the Future, National Archives of Singapore, Singapore, 6 September.

- 2007. "Pak Ardan; Antara Melayu-Pasar dan Melayu-Tinggi," paper for Diskusi Buku-buku Karya SM Ardan, Dewan Kesenian Jakarta-Taman Ismail Marzuki, Jakarta, 23 Februari.

- 2007. "Pictorial Images of the Indonesian Chinese during the Revolution 1945-1949," paper for International Workshop on Public Eyes/Private Lenses: Visualizing the Chinese in Indonesia and in North America, University of British Columbia, Vancouver, 1-3 March.

- 2008. "Pengalaman menulis sejarah lokal Batavia," paper for Sosialisasi Pedoman Penulisan Sejarah Lokal, Direktorat Nilai Sejarah, Departemen Kebudayaan dan Pariwisata, Banjarmasin, 22-25 April.

- 2009. "Perempuan Indonesia dalam Sejarah," opening discussion for course on "Posisi Perempuan Indonesia dalam foto sejarah zaman kolonial," Jurusan Antropologi FISIP, Pusat Kajian Antropologi Indonesia, Universitas Indonesia, Depok, 19 February.

— 2009. "The Office for Chinese Affairs; Dutch Politics of Ambivalence," Fourth International Conference of Institutes and Libraries for Chinese Overseas Studies, Jin'an University, Guangzhou, 9-12 May.

- 2009. "Mencari Jejak Sumber Sejarah Maritim," Sosialisasi Pedoman Penulisan Sejarah Lokal, Direktorat Nilai Sejarah, Dirjen Sejarah dan Purbakala, Departemen Kebudayaan dan Pariwisata, Makassar, 26-29 May.

- 2010. "British Rule in Java, 1811-1816; Glimpses at the archives," Third Encompass Conference, University of Mumbai, Mumbai, 12-15 January.

\section{Articles about, and Interviews with, Mona Lohanda}

-2004. "Supersemar sangat berbau politik: Wawancara," Sinergi Indonesia 2.21 (November):9. Djie, S.H. 2012. "Mona Lohanda: Een beschieden nationale persoonlijkheid," Hua Yi Xie Shang Hui 25.3 (September): 38-41. 